\title{
Richbpal Singh Meena v. Ghasi: Past Eclipse of India's Substantive Criminal Law in Contemporary Operation
}

\author{
Jaideep Singh Lall*
}

\begin{abstract}
The Indian Supreme Court's verdict in Richbpal Singh Meena v. Ghasi is a marked peripeteia in the legal position on the applicability of offences under the two sub-chapters of Chapter XVI of the IPC in the heads of sections dealing with 'Offences Affecting Life' and 'Hurt'. In essence, this ruling declared that scenarios that end with death of the victim will mandatorily have to be only covered by the sub-chapter 'Offences Affecting Life', making 'actus reus of fatal results' the determinant for choosing the offence for which the accused is to be convicted. After providing a factual frame of reference, this paper recapitulates the key elements of the Court's reasoning in arriving at this principle. The main thrust of the paper lies in its analysis of the Court's faulty neologisms and legally inconsistent alterations in the yardsticks that govern which cases fall under either of the two heads. This paper argues that the Court's ratio decidendi and the principles it has evolved represent nothing short of insouciance towards decades of clarificatory precedent and that they are ex facie since Richbpal's ruling engenders injustice in situations where the intention is to only cause burt, but death results regardless of the intention transpired. As a judgment made in 2014, this ruling continues to breed iniquitous convictions even to this day. It is this examination of the judgment's myopia for the past and its eclipse on the present delivery of justice that represents the central thesis of this paper.
\end{abstract}

In 2014, while adjudicating a Criminal Appeal, a division bench comprising of Justices Ranjana P. Desai and Madan B. Lokur of the Hon'ble Supreme Court of India upended decades of jurisprudential progress on the distinct application of sections under the two separate heads 'Offences Affecting Life' and 'Hurt' in Chapter XVI of the Indian Penal Code 1860 ('IPC'). The judgment in Richhpal Singh Meena v. Ghasi' effectively

\footnotetext{
* Jaideep Singh Lalli is a final year law student, reading for B.A. LL.B. (Hons.) at the University Institute of Legal Studies, Panjab University, Chandigarh, India. He can be reached at jaideepsingh013@gmail.com. He has previously published with the University of Oxford Human Rights Hub Journal, Statute Law Review (Oxford University Press), NALSAR Student Law Review, and more.

1 Richhpal Singh Meena v. Ghasi, Supreme Court of India, 2014, B SCC 918. ("Richhpal Singh Meena case")
} 
foreclosed the possibility of modifying a conviction under section 302 of the IPC ${ }^{2}$ to one under sections $323^{3}, 325^{4}$ or any other appropriate section under the 'Hurt' head in Chapter XVI of the Code. The Court in essence laid down that as long as the result of the accused's assault is death, they cannot be covered by offences under the 'Hurt' chapter. This marks a tectonic shift in the conception of what determines an apposite conviction by supplanting the 'mens rea determinant' with one that is based solely on whether post the infliction of injuries, a death has occurred or not. This has dangerous ramifications for scenarios where intention was only to cause hurt (not death) and it could not have reasonably been foreseen that the act would result in death. Now, as per Richhpal's dictum, such a person would have to be punished under the 'Offences Affecting Life' chapter. Considering that the judgment has not been expressly overruled yet, it continues to engender confusion on questions surrounding murder and hurt convictions inasmuch that courts continue to render conflicting judgments on what the correct legal position is.

\section{Contextualising the Ratio Decidendi}

The division bench's ratio on the relevance of the 'Hurt' chapter in cases where injury results in death was largely based on its disgruntlement with the High Court's application of law in the facts of the instant case. Hence, it would be instructive to view the Court's reasoning through the lens of the case's circumstantial context.

\section{A. Factual Background: A Violent Countryside Scrimmage}

On 14 December 1996, Richhpal Singh Meena ('the appellant') and a couple of others were sitting next to a well close to agrarian fields. The appellant's father Sunderlal Meena ('the deceased') had gone to examine the fields. While he was there, he met Kailash, Ghasi, Lala, their individual spouses and their mothers. Before long, there was a heated altercation between them concerning damage to the dike in the fields.

Kailash, Ghasi and Lala declared that they had been searching for Sunderlal and he had now strolled into their snare on his own. Saying this, Kailash seized Sunderlal; Ghasi gave him a blow with a shovel and Lala struck the deceased on his back with a lathi. Consequently, the deceased tumbled down and on hearing all the clamour, the appellant and others rushed to the site and saw that the deceased was being beaten by women. With the help of the individuals who were with him, the appellant took the deceased to a hospital in Alwar. But the deceased succumbed to his injuries.

The post-mortem examination of the deceased's body revealed that two injuries inflicted on the deceased were sufficient in the ordinary course of nature to cause death, where

Indian Penal Code, 1860, India, s. 302, punishment for murder.

Ibid, s. 323, punishment for voluntarily causing hurt.

Ibid, s. 325, punishment for voluntarily causing grievous hurt. 
the cause of death was attributed to shock, haemorrhage and lung injuries. Based on this factual matrix, a charge-sheet for offences under sections 302, 302 read with $34^{5}$ and 447 of the IPC, was filed against both Ghasi and Lala.

\section{B. Judicial Proceedings: The Reversal Saga}

The Additional District \& Sessions Judge, Alwar convicted both the accused for offences punishable under sections 302 and 447of the IPC while acquitting them of the charge of section 302/34. Discontented, the convicts preferred an appeal before the Rajasthan High Court, which by a judgment dating back to 16 April $2003^{6}$ acquitted them for offences under section 447 read with 302 and altered their conviction under section $302 / 34$ of the IPC to one under section 325/34.

Feeling aggrieved on this modification of conviction, the appellant filed an appeal at the Apex Court. ${ }^{7}$ The Supreme Court noted that the High Court wrongly recorded that the accused had ever been convicted of a charge under section 302/34, when the trial court's verdict referred only to sections 302 and 447 . The Court in the instant judgment then, reversed the order of the High Court and restored the verdict of the trial court by holding the accused liable for murder for the reason that the accused intended to inflict the injuries and such injuries were sufficient in the ordinary course of nature to cause death, as per the medical evidence adduced.

\section{Key Elements of the Court's Reasoning}

The Apex Court in the instant case held in unequivocal terms that treating cases involving homicidal deaths as matters of voluntarily causing grievous hurt was impermissible, as the 'Hurt' chapter did not aim to cover scenarios that involved death as the end result. ${ }^{8}$ The foundations of this ruling can be studied under the following heads.

\section{A. Conceptualisation of Homicide in the Indian Penal Code}

In the words of Justice Lokur, the IPC mainly deals with three kinds of homicides?: (i) culpable homicide amounting to murder, as defined in section $300^{10}$ and punishable under section 302; (ii) culpable homicide not amounting to murder, as defined as

\footnotetext{
$5 \quad$ Ibid, s. 34, acts done by several persons in furtherance of common intention. Ghasi v. State, Rajasthan High Court, Criminal Appeal No. 403 of 1997.

Richbpal Singh Meena Case (n 1).

'Richhpal Singh Meena v. Ghasi', The Practical Lawyer, available at www.supremecourtcases. com $/$ index2.php?option $=$ com_content\&itemid $=99999999 \&$ do_pdf $=1 \&$ id $=46285$, accessed on 13 June 2020.

9 Section. 304Bof the IPC was excluded from consideration by the Supreme Court of India for it was not concerned with its discussion.

10 Indian Penal Code, 1860, India, s. 300, murder.
} 
a genus in section $299^{11}$ and punishable under section 304'12; and (iii) 'not-culpable homicide' defined and punished under section $304 \mathrm{~A}^{13}$. What the Court meant by the last neologism was that a rash or negligent act that causes death would not be covered by either of the two types of 'culpable homicides' if the person who committed the act lacks the requisite intention or knowledge for culpable homicide amounting or not amounting to murder; instead, it would be dealt under section $304 \mathrm{~A}$, which is a species of homicides that is different from 'culpable homicide' as defined under section 299, therefore it is 'not-culpable homicide'. Based on this understanding of the scheme of the IPC, the Court concluded that in case an accused's act or omission causes the death of a person, his guilt can only fit into either of the three pigeonholes and nothing else.

\section{B. The Jurisprudential Hymn \& The Five-Step Inquiry}

After summarising the precedent ${ }^{14}$, the Court asseverated that those sections in the IPC under the 'Hurt' chapter (sections 319-338) does not deal with situations where death is the end result. To advance this proposition, the Court even went to the extent of saying that such a claim is not only evident in the arrangement of sections in the IPC but also clear from the fact that clause eight of section $320^{15}$ only embraces hurt that endangers life, and does not explicitly include hurt that extinguishes life. With that the Court declared, 'if hurt results in death, intended or unintended, the offence would fall in the category of an offence affecting life' and not in the category of offences relating to hurt.

Emanating from that jurisprudential perception of the IPC, the Court laid down a five-step inquiry to ease the process of fastening appropriate liability in homicide cases. The pith and core of that inquiry is that after the Court has determined that a homicide has occurred, it has to suitably fit the accused's conviction in either of the three compartments (culpable homicide amounting to murder, not amounting to murder or 'not-culpable homicide'). The Bench applied this inquiry in the facts of the instant case to classify the matter as a culpable homicide amounting to murder, and to restore the trial court's verdict by reasoning that the IPC's scheme did not allow the alteration of a homicide conviction to one under section 325 .

\section{Probing the Problematic dictum}

\section{A. The Infelicitous Expansion of Section 304A's Scope}

The Bench's conclusions on what the IPC envisages are contra legem for several reasons.

\footnotetext{
$11 \quad$ Ibid, s. 299, culpable homicide.

12 Ibid, s. 304, punishment for culpable homicide not amounting to murder.

13 Ibid, s. 304A, causing death by negligence.

14 Rajwant Singh v. State of Kerala, Supreme Court of India, 1966, AIR 1874; Virsa Singh v. State of Punjab, Supreme Court of India, 1958, AIR 465; Abdul Wabeed Khan v. State of AP, Supreme Court of India, 2002, 7 SCC 175.

15 Indian Penal Code, 1860, India, s. 320, grievous hurt.
} 
The judgment states that in case the accused person does the injury unintentionally, they would be punished under 'not-culpable homicide' by section 304A. Such a characterisation of section 304A belies its true purport. Added by the 1870 Amendment Act $^{16}$, section 304A was incorporated to provide a lighter punishment in specific cases of homicide caused by rash or negligent acts. It was never a catch-all charge or a residuary section aiming to capture all homicidal deaths that did not fulfil the essentials of culpable homicide not amounting or amounting to murder. The section only covers that class of offences where death is caused neither intentionally nor with the knowledge that the offender's act is likely to cause death, but because of the rash and negligent act of the offender. ${ }^{17}$ Therefore, the specific requirements of proving culpable rashness or negligence leaves out various homicidal instances where the mens rea falls short of culpable homicide but the act is still not a result of rashness or negligence.

Further, the Court effectuates terminological inexactitude when it designates $304 \mathrm{~A}$ as 'not-culpable homicide', implying that whatever is not covered by culpable homicide subsumes under section 304A. The legislative intent to the contrary is with large in the title of section 304A itself, which refers to the section as 'death by negligence' (and not as 'not-culpable homicide'), perspicuously denoting that the section is narrowly tailored for a definite class of cases. This principle has been abundantly obvious historically as well; as early as in 1881, the Allahabad High Court in Empress of India v. Idu Beg ${ }^{18}$, clarified that section 304A does not punish every unjustifiable or inexcusable act of killing that does not fall under either of the two descriptions of culpable homicide, instead its ambit is limited to rash or negligent acts that causes death but falls short of culpable homicide or murder. This was a case where the accused while engaged in a verbal argument with his wife, struck her on the left side of her face with such a great force that she bled from the nose and died soon after. Illuminating the distinct scope of sections 299, 300 and 304A, the Court held the accused liable under section 325 (even though death had been caused in the matter) because there was no homicidal intention or knowledge.

If it was for the Bench in Richhpal, the accused would have walked free since his mens rea would have failed to meet the essentials of any of the three categories the Court delineated in the judgment made in 2014. Culpable rashness denotes indifference for consequences and negligence connotes gross neglect and failure to exercise reasonable care $^{19}$, and as section 304A's essentials, they encompass factual settings that are incommensurable to the scope of hurt or grievous hurt and their sections. The ex-facie fallaciousness of the Supreme Court's conceptualisation in Richhpal and its contrast with comparative perspectives from English law would become apparent from the

16 Indian Penal Code (Amendment) Act, 1870, India, s. 12.

17 V I Vibhute, PSA Pillai's Criminal Law, LexisNexis, Gurgaon, 13th edition, 2019, p. 663; for explication of what culpable rashness and negligence involve, see Emperor $v$. Abdul Latif, Lahore High Court, 1944, AIR 163; SN Hussain v. State of AP, Supreme Court of India, 1972, AIR 685; State of Himachal Pradesh v. Mobinder Singh, Himachal Pradesh High Court, 1989, 2 Crimes 159; Ravi Kapur v. State of Rajasthan, Supreme Court of India, 2012, AIR 2986.

18 Empress of India v. Idu Beg, Allahabad High Court, 1881, SCC OnLine All 103.

19 Bhalachandra Waman Pathe v. State of Maharashtra, Supreme Court of India, 1968, AIR 1319. 
Allahabad High Court's reasoning in the $I d u$ Beg case which deserves to be reproduced in extenso for the sake of clarity: ${ }^{20}$

"The category of intentional acts of killing, or of acts of killing committed with the knowledge that death, or injury likely to cause death, will be the most probable result, or with the knowledge that death will be a likely result, is contained in the provisions of ss. 299 and 300 of the Penal Code. S. 304 creates no offence, but provides the punishment for culpable homicide not amounting to murder, and draws a distinction in the penalty to be inflicted, where, an intention to kill being present, the act would have amounted to murder, but for its having fallen within one of the Exceptions to s. 300, and those cases in which the crime is culpable homicide not amounting to murder, that is to say, where there is knowledge that death will be a likely result, but intention to cause death or bodily injury likely to cause death is absent. Putting it shortly, all acts of killing done with the intention to kill, or to inflict bodily injury likely to cause death, or with the knowledge that death must be the most probable result, are prima facie murder, while those committed with his knowledge that death will be a likely result are culpable bomicide not amounting to murder. Now it is to be observed that s. $304 \mathrm{~A}$ is directed at offences outside the range of ss. 299 and 300, and obviously contemplates these cases into which neither intention nor knowledge of the kind already mentioned enters. For the rash or negligent act which, is declared to be a crime is one "not amounting to culpable bomicide", and it must therefore be taken that intentionally or knowingly inflicted violence, directly and wilfully caused, is excluded. S. 304A does not say every unjustifiable or inexcusable act of killing not hereinbefore mentioned shall be punishable under the provisions of this section, but it specifically and in terms limits itself to those rash or negligent acts which cause death but fall short of culpable bomicide of either description.

According to English law, offences of this kind would come within the category of manslaughter, but the authors of our Penal Code appear to have thought it more convenient to give them a separate status in a section to themselves, with a narrower range of punishment proportioned to their culpability. It appears to me impossible to hold that cases of direct violence, wilfully inflicted, can be regarded as either rash or negligent acts. There may be in the act an absence of intention to kill, to cause such bodily injury as is likely to cause death, or of knowledge that death will be the most probable result, or oven of intention to cause grievous hurt, or of knowledge that grievous burt is likely to be caused. But the inference seems irresistible that hurt at the very least must be presumed to have been intended, or to have been known to be likely to be caused. If such intention or knowledge is present, it is a misapplication of terms to say that the act itself, which is the real test of the criminality, amounts to no more than

20 The Allahabad High Court's illuminating exposition in the Idu Beg case was recently cited with approval by the Andhra Pradesh High Court in PPC Mohan Rao v. State of Andhra Pradesh, Andhra Pradesh High Court, 2020, SCC OnLine AP 550. 
rashness or negligence. In the present case the evidence is clear that the blow was wilfully and consciously given to the deceased woman by the accused, and he obviously therefore committed an assault at the very least. The consequences that resulted from it could not change a wilful and conscious act into a rash or negligent one, but their relevancy and importance, as indicating the amount of violence used, bore upon the question as to the character of the intention or knowledge to be presumed against the accused."

\section{B. The Yardstick Alteration: Disregarded Maxims and Snubbed Precedent}

The aforementioned fault in discerning the IPC's scheme would appear to be a mere peccadillo when the judgment's greatest flaw is acknowledged. As indicated by the Idu Beg case, the determination of the applicability of the IPC sections (under the heads 'Offences Affecting Life' and 'Hurt' in Chapter XVI) has never been contingent on whether death is the end result of the act or not; rather, it is based on the sweep of mens rea. The ascertainment of the proper charge is based on the settled principle that a person must only be punished for the hurt they intended to cause or knew would likely be caused as a result of their act, and that no one should be penalised for unfortunate and completely unforeseen results of the act done. Following this canon of criminal justice, in a concatenation of judgments, the accused has only been punished for causing hurt or grievous hurt even when death occurred as a result of their actions.

In Public Prosecutor v. Muttia ${ }^{21}$, when death was caused as a result of stick blows on the deceased's buttocks and thighs with the object of chastisement, the accused was only convicted for simple hurt under section 323 since the intention or knowledge requisite for fixing liability for culpable homicide of either description was absent. In Urmese $v$. State of Kerala ${ }^{22}$, the accused had given a single blow with open hand on the neck of the deceased. This act was not followed by any other violence. However, the blow caused a fracture of the vertebrae and the victim died. The offence was only held to be one under section 323 .

In Anil Kumar v. State of Rajasthan ${ }^{23}$, on a sudden argument, the accused gave a single kick to the abdomen of the deceased. The kick caused a rupture in the small intestine and the deceased eventually died. But the accused was only held liable under section 325. In Mabindar Singh v. Emperor ${ }^{24}$, the deceased's death was caused by the setting in of tetanus almost a week after the accused inflicted an injury on the deceased's leg with a gandasa. However, the accused was only held liable under section 324.

In Empress of India v. O'Brien ${ }^{25}$, the accused kicked the deceased, due to which his already enlarged spleen ruptured and he died. There was neither the intention to cause death

\footnotetext{
$21 \quad$ Public Prosecutor v. Muttiah, Andhra Pradesh High Court, 1961, AIR 79.

22 Urmese v, State of Kerela, Kerala High Court, 1960, AIR 197.

23 Anil Kumar v. State of Rajasthan, Rajasthan High Court, 2012, SCC OnLine Raj 2123.

24 Mahindar Singh v. Emperor, Lahore High Court, 1924, SCC OnLine Lah 358.

25 Empress of India v. O’Brien, Allahabad High Court, 1880, SCC OnLine All 109.
} 
or such bodily injury as was likely to cause death, nor any knowledge that the act of kicking the deceased was likely to cause death. The accused therefore, was only held liable under section 325. What is even more interesting is that the Court specifically emphasised that section 304A had no application since it had its own essentials of culpable rashness or negligence which are unsuited to such cases of wilful infliction of injury.

A perusal of the judgments in all these cases render the inescapable inference that the Bench in Richppal formed an opinion on the IPC's statutory operation while being oblivious to a long line of precedent shedding light on the question. All the abovementioned decisions provide situational examples of cases where Richhpal's dictum produces unsatisfactory results. Since the only way a case falling short of culpable homicide of either description could be punished in Richhpal's paradigm is by bringing it under section $304 \mathrm{~A}$, the accused in all the above scenarios would either get acquitted ${ }^{26}$ or be awarded lesser punishment ${ }^{27}$ for causing grievous hurt which otherwise occasions a higher degree of punishment. It is to avoid these loopholes that the yardstick for deciding which sections under the two heads of Chapter XVI appropriately cover an accused's liability in a particular case has always been the 'degree of mens rea' and not 'actus reus of fatal results'.

Moreover, there is nothing apart from Justice Lokur's speculation to indicate that the arrangement of sections in the IPC reflects a legislative intent to restrict the application of the 'Hurt' chapter only to instances of victims who survive the assault, to the exclusion of those who succumb to their injuries. In that regard, it is submitted that the legal position laid down by the cases cited above is more desirable, for reductio ad absurdum necessitates its acceptance in light of the absurdity of the alternative that Richbpal proffers.

\section{Examining the Judgment's Application by India's High Courts}

Recently, in Mebtab Singh v. State of Haryana ${ }^{28}$, the accused persons had attacked the deceased due to an earlier quarrel and had struck a blow to his abdomen. He died as a result of septicemia. In this matter, instead of holding the accused liable under section 325 , the Court held the accused liable under section 304A. It is unclear how that verdict can be reconciled to the Court's recognition of the fact that the accused came with the intention of causing injuries to the deceased. The intention and knowledge fell short of causing death or such bodily injury that is likely to cause death since the accused did not repeatedly strike the deceased in the abdomen, however, that by itself does not serve the proof of any rashness or negligence on the part of the accused. The judge

\footnotetext{
$26 \quad$ Since willful infliction has been held to be the privation of s. 304A's application, proving why the section still applies would be abhorrent jurisprudentially; see Pitala Yadagiri v. State of Andhra Pradesh, Andhra Pradesh High Court, 1991, 2 Crimes 359; Shiv Dev Singh v. State (Delhi), Delhi High Court, 1995, Cr LJ 2142.

27 Imprisonment of two years or fine or both.

28 Mehtab Singh v. State of Haryana, Punjab \& Haryana High Court, 2019, SCC OnLine P\&H 1025.
} 
categorized the case as one of culpable rashness and negligence only because Richhpal's dictum ordained against a conviction under section 325 in cases of the victim's death. What standard of 'reasonable care' did the persons who came with the intention of causing injuries fail to exercise? of not hitting the deceased with less force? But, isn't hitting the deceased with the force they did exactly what they wanted to do? If yes, then how is this intentional act 'more appropriately' covered by a section that punishes death by negligence and not by one that punishes the very act the accused intended? This case is a fitting proxy to discern how problematic the ruling in the Richhpal case really is.

In contrast to the Punjab \& Haryana High Court's judgment in the case of Mebtab Singh is the reasoning of a Division Bench of the Allahabad High Court in Ragbubir v. State of Uttar Pradesh ${ }^{29}$ In the facts of that case, no attempt was made to assault the deceased on his chest, or to make any other assault on the head or other vital part of his body. Much like in Mehtab Singh, from a perusal of the injuries, the High Court observed that there was no intention to cause the death of the deceased or even to cause any fatal injury to the deceased, though there could have been a common intention to cause grievous injuries to the deceased, which had in fact been caused. Even though the State's counsel had expressly relied on Richhpal's ratio, the High Court found its application to be inappropriate. Citing Section 72 of the IPC, the Court eventually held:

"In view of this provision also, as a doubt has been raised as to whether on the
disclosed facts the appellants are guilty of murder or only of causing grievous
injuries which had resulted in the death or the deceased, we think that it would
be more appropriate for this Court to award the punishment for the lesser offence
which in the background of the present case would fall under section $326 / 34$
IPC and not under section 302 IPC for causing the death of Kheoraj..."

\section{Conclusion}

By modifying section 302 conviction to one under section 325 even after the judgment in Richhpal had been delivered ${ }^{30}$, the Apex Court has already set in motion a disconcerting exercise of furnishing judgments with inconsistent tenets and no engagement with conflicting pronouncements. Courts in the country continue to follow Richhpal's 'fivestep inquiry' and its ordainments relating to sections in the 'Hurt' chapter regardless. ${ }^{31}$ This milieu of oppugnant orders sounds the death knell for legal uniformity, which is not propitious for the development of criminal jurisprudence in view of the postulate that legislation prescribing criminal liability is to be interpreted strictly. As Mebtab Singh's case has illustrated, the operation of the principles evolved in Richhpal is causing sinister setbacks in the administration of criminal justice. On account of this, a review by a

Raghubir Singh v. State of Uttar Pradesh, Allahabad High Court, 2015, SCC OnLine All 5590.

See Govindaswamy v. State of Kerala, Supreme Court of India, 2016, 16 SCC 295.

See Pashupati Nath Jha v. State of Bihar, Patna High Court, 2014, SCC OnLine Pat 5568; Manoj v. State of Uttarakhand, Uttarakhand High Court, 2019, SCC OnLine Utt 1449; Shiv Bahadur Ram v. State of UP, Allahabad High Court, 2019, SCC OnLine All 4377; Dhampal v. State (NCT Delhi), Supreme Court of India, 2020, SCC OnLine SC 421. 
bench of greater strength of this 2014 Supreme Court judgment would be prudent, as rectification of erroneous pronouncements is the prerequisite for counteracting injustice in the determination of guilt. 